\title{
Implementation of Character Education Values at Grade IV of SD IT Bina Ilmi Palembang
}

\author{
Laihat \\ Sriwijaya University \\ Palembang, Indonesia \\ laihat.90@gmail.com
}

\begin{abstract}
The purpose of the study is to describe the implementation process of the educational value of student character from grade IV with the focus of religious point, discipline, and environmental care. This study is a quantitative descriptive study with an amount of the samples as many as 57 students. The technique of data retrieval is using systematic sampling technique. Data collection is done by using observation, interview, questionnaire, and documentation. Analysis of quantitative data measured based on Likert's scale which presented in category "sufficient"-75,00), $(\mathbf{5 6 , 0 0 " d e f i c i e n t "}$ $(<56,00)$. Th the implementation of education character value which integrated via self-development program, subjects and school culture in SD IT Bina Ilmi including the value of religious character (pray, mentoring, tilawah tahfidz qur'an, duha prayer and dzuhur prayer, greetings and regrads, young DAI, and write out hadist or signs of Allah on RPP sheet) based on questionnaire result, the value of religious character get a percentage of the value of $(89,48 \%)$ and including in the categoryof "good", the value of discipline char following the flag ceremony, collect books cooperation, class picket, taking care ofschool facilities, do not bring electronic stuff and do not use footwear while entering the class) based on the questionnaire of discipline character value get a percentage of the value of $(75,43 \%)$ and includingeof $i$ environmental care character (maintain the cleanliness class, throw the garbage in its place, not picking plants, utilize existing facilities as a means of plants as well, and designing hydroponics) based on the resultof questionnaire of environm care character get a percentage of the value of $(\mathbf{7 3 , 8 6 \%})$ and including the category of "sufficient".
\end{abstract}

Keywords-Implementation; character value; SD IT

\section{INTRODUCTION}

Education is an important aspect for everyone because it is a process of self-development by people continue to improve their capabilities. In the National Education No. 20 of 2003 article 03 mentions that one of the objectives of the National Education is to develop students' potentials in order to be the faithful and devout person to the almighty God and also own a noble character. But in observations, goal of the education has not applied optimally, it happens because there are still many educational units more giving a priority to the benchmark IQ than the benchmark SQ, consequently the fundamental problems faced by schools today is a moral, so that solution issued by the Ministry of Education and Culture in overcoming the moral issues is the need for the character education [1].
The character education is starting to be applied to the curriculum in 2013, especially at the level of elementary schools where more emphasis on the attitude aspects than the cognitive and psychomotor aspects. In the curriculum of 2013, there are 18-character values issued by the Ministry of Education to support the education of character itself so that to carry out the character values is required a habit [1].

The character education in schools can be integrated through the self-development, subjects, and culture of the school. Several efforts can be done by the schools in implementing values of the character education are to create an environment of the school that reflects the culture characters that it can be reflected through a school curriculum, vision and mission of the school, programs of school, models and extracurricular activities. These efforts will not be integrated properly if there is no involvement of all components of school and not only responsibility of teachers of religion as it began to be applied in SD Islam Terpadu Bina Ilmi Palembang.

From the overall values of characters, there are three character values that more implemented dominantly in school which it is reflected in the vision and mission of school, religious values, discipline and care for environment so that the researcher is interested to learn more about the implementation process of the characters values with the formulation of problems are (1) "How is the implementing process of character education values for the fourth grade students of Bina Ilmi Palembang?". (2) "What are the obstacles faced and the solutions strove by the school in the implementing process of the character education values for the fourth-grade students of Bina Ilmi Palembang?"

The purposes of this study are: (1) "Describe the implementation process of the character education values applied to the fourth-grade students of SD Islam Terpadu Bina Ilmi Palembang". (2) "Describe the obstacles and solutions in the implementing process of the character education values in SD Islam Bina Ilmi Palembang", while the benefit of this research theoretically is: "Provide information that can expand the knowledge on the implementation of character education values". Practically this research has benefit for school: "Provide an overview about the implementation process of character values in school in the next time that it can be used as an evaluation material in refining an implantation system of character values". For teachers: "Increase a motivation of 
teachers to integrate the characters values in the learning process". For researchers: "Add an experience to expand their knowledge about the implementation of character values so that it can be a guidance in next time".

\section{METHOD}

\section{A. Type of Research}

This research type is a quantitative descriptive research conducted in SD IT Bina Ilmi Palembang to describe: Implementation of character education values for the fourthgrade students of SD IT Bina Ilmi Palembang.

\section{B. Population and Sample}

The population in this research is all fourth-grade students and uses a systematic sampling amount to 57 students.

\section{Data Collecting Techniques}

The data collecting techniques use as follows:

\section{1) Observation}

The researcher obtains the information and data of the implementation of character value through a self-development and culture od school.

\section{2) Interview}

This interview technique is conducted with five homeroom teachers for the fourth grade of SD IT Bina Ilmi Palembang to obtain data regarding the implementation of character values through subjects.

\section{3) Questionnaire}

The questionnaire filling technique will be given to students to measure how much percentage of religious character value, discipline, and care for the environment has been applied.

\section{4) Documentation}

By using the documentation technique, the researcher obtains data in form of school guideline book, syllabus, RPP and the teachers'education history.

\section{Data Analysis Technique}

To analyze the data that has been collected, the researcher will describe an outline of implementation process of the character education value in SD Islam Bina Ilmi Palembang as religious values, discipline, and care for the environment obtained from the observation, interview and documentation. While, according to the type of data and processing method, the researcher uses analyzed questionnaires of Linkert Scale by using a frequency distribution analysis so that the obtained results are in the form of numbers.

\section{RESULTS AND DISCUSSION}

\section{A. General Description of SDIT Bina Ilmi Palembang}

\section{1) Description of Research Place}

SD Islam Terpadu Bina Ilmi Palembang is a school that located in Jl. Letjen Alamsyah Ratu PrawiranegaraNo. 78 RT. 01 RW. 06 Bukit Baru III, Ilir Barat I Palembang, SouthSumatera Province which it was founded in 2006. The SD Islam Terpadu Bina Ilmi Palembang is located very close to the main road access to the Musi Dua, and it has a conducive environment as a learning place with a land area of $3,000 \mathrm{~m}^{2}$.

\section{2) Vision and Mission}

The vision of SD IT Bina Ilmi Palembang is to create the honest students in faith, superior in character, competitiveness in achievement, own a good character, productive, and own environmentally thinking. While the primary missions of SD IT Bina Ilmi Palembang are: 1) Implant an honest faith. 2) Allowing worship properly. 3) Increase the noble character, good manners and model attitudes. 4) Establish the intellectual environment that is close to the Al-Quran. 5) Develop a critical culture, self-actualization, and the talent and interest channeling. 6) Encouraging the self-potential in applying the possessed knowledge.7) Increase social attitudes as well as concern for the environment. 8) Optimizing a partnership between schools, families, and communities.

\section{B. Implementation of Character Education Values for Grade IV Student of SD IT Bina Ilmi Palembang \\ 1) Implementation of Character Education Values through self-Development}

The integration of character education through the selfdevelopment in SD IT Bina Ilmi Palembang is conducted through routine activities, spontaneous activities, models, and conditioning. The routine activities are activities carried out continuously [2]. As for the forms of the conducted routine activities are to conduct the flag ceremony, prayers before and after studying, class picked, sholat dhuha and dzuhur, activities of Tahfiz Quran recitations, mentoring activity and collect the corporate books every morning. While the spontaneous activities are activities carried out on the spot [2]. Teachers can also be described as a "No matter how brilliant your plan if will not work if you do not set an example" however brilliant your plan, it will not run if it is not accompanied by a model. The form of model that applied SD IT Bina Ilmi Palembang is getting used to greetings and regards, close the genitals and dressed neatly, get used to write basmalah and hamdallah before and after studying, and take the trash. The latest activity is a conditioning where it can be interpreted as an attempt of school to organize the physical environment [3]. The conditioning conducted in SD IT Bina Ilmi Palembang is to make a garden in a small space, seating facilities utilization, posters and displays the character value, providing cleaning tools, providing a wudhu place and also a mosque.

\section{2) Implementation of Character Education Values through Subject}

Implementation of the character education values through the subject means that "the introduction of values into the 
behavior of students daily through a learning process, both in the inside and outside the classroom" [2]. The character values that implemented in the activities of learning process in the classroom, most of the development of character values in the syllabus and RPP wherein the implementation process is adjusted to a core competencies and a basic competencies and also indicators to be achieved during the learning process so that with a good planning, it helps the learning implementation for teachers and learners know certainly the objectives to be achieved [4]. However, the statement is not accordance with the fact because the teacher has not specified in writing the characters values in the syllabus though, in the RPP, the character values have included mainly the value of the religious character because it is based on the research that researcher get that in the RPP are required to include the hadist or verse of Allah relating to the material.

\section{3) Implementation of Character Education Values through Culture of School}

The good school culture will create the desired output in the form of good character values. The implementation of character education values through the school culture can be conducted in the classroom, school, out of school and extracurricular activities. Based on the observation of the integration of school culture through a classroom activities is displaying the students' work and also cultivate the reading interest, whereas through the school activities is to provide facilities for students to participate in activities commemorating the national great days and Islamic great days, for example the ceremony of August 17 th, cheer ramadhan, Muharram Expo and teachers' day, while activities of outside school is to follow aneducative visit conducted once every semester to a place directly related to the learning materials, then the extracurricular activities that provided by the school is extracurricular of dancing, young Dai, robotics, and a scouting movement. All these activities are in accordance with the main design of character education designed by the Ministry of National Education in 2010 that: the strategy of the character education development that applied in Indonesia, among others through the culture of schools and through extracurricular activities".

\section{4) Tables of character values}

The questionnaire results of the religious values are obtained, where the religious values obtain a good percentage to indicate a frequency of $89.48 \%$ for the students in good category and $10.52 \%$ of students in enough category and it already exceeds the minimum percentage amount that has been determined in the good category.

\section{TABLE I. RELIGIOUS VALUES}

\begin{tabular}{|ll|}
\hline \multicolumn{1}{|c|}{ Activities of Religious Value } \\
\hline - & Saying greetings and regards \\
- & Sholatsunnah and dzuhur \\
- & Reading studying pray \\
- & Activities of mentoring \\
- & Recitation of Tahfiz Quran \\
\hline & Charity visits \\
\hline
\end{tabular}

- $\quad$ Young Daiextracurricular

- Commemorating the Islamic great days

The obtained questionnaire results indicate that the character values of discipline are still in enough percentage with the frequency of $75.43 \%$ in the good category, $15.78 \%$ in enough category and $8.77 \%$ less category.

TABLE II. DISCIPLINES VALUES

\begin{tabular}{|ll|}
\hline \multicolumn{1}{|c|}{ Activities of Disciplines Values } \\
\hline - & Present on time \\
- & Dressing uniforms are neat and close the genitals \\
- & Conducting a ceremony every Monday the corporation books every day \\
- & Implementing the picket duties \\
- & Mot carrying the electronic goods \\
- & Do not wear footwear (slippers/shoes) in the classroom. \\
- & Providing a sanction against students who violate rules \\
\hline
\end{tabular}

TABLE III. ENVIRONMENTAL CARE VALUES

\begin{tabular}{|ll|}
\hline \multicolumn{1}{|c|}{ Activities of Environmental Care Values } \\
\hline - & Maintaining the cleanliness of class \\
- & Throw garbage in its place \\
- & Not picking plants \\
- & Utilize the seating facility as a place to plant \\
\hline
\end{tabular}

The obtained questionnaire results indicates that the character values of environmental care is still indicating a frequency of $73.68 \%$ of students in good category, $22.80 \%$ of students in enough in enough category and $3.50 \%$ of students in less category that needs to be evaluated in effort to increase the character value of environmental care in order to be better.

\section{CONCLUSIONS}

The research results on implementation of character educationvalues that integrated through the self-development program, subjects and culture of school in SD Islam Terpadu Bina Ilmi Palembang include the religious character values (prayer, mentoring, recitations of Tahfiz Quran, sholatdhuha, and dzuhur, greetings and regards, young Dai, as well as hadist or verse of Allah to write on sheets RPP) based on the results of questionnaire, the religious character values are obtainedthat the value percentage amount to $(89.48 \%)$ and included in a category 'good' and it is in accordance with the vision of SD IT Bina Ilmi which focuses on the religious values, the value of the discipline character (present on time, close the genitals, following the flag ceremony, collectthe copperation book, classpicket, maintaining school facilities, not bring electronic goods and not wear a footwear to enter the classroom.

\section{REFERENCES}

[1]. Yaumi. 2014. Pendidikan karakter landasan,pilar dan implementasi. Jakarta: Prenadamedia Group.

[2]. Gunawan. 2014. Pendidikan Karakter Konsep dan Implementasi. Bandung: Alfabeta

[3]. Indrastoeti SP Jenny. 2012. Penanaman Nilai-Nilai Karakter Melalui Implementasi Pendidikan Karakter di Sekolah Dasar.290-291 
[4]. Mulyasa. 2013. Manajemen Pendidikan karakter. Jakarta: PT.Bumi Aksara.

[5]. Arikunto. 2006. Prosedur Penelitian Suatu Pendekatan Praktik. Jakarta: Rineka Cipta 